\title{
Transfer of Faenia rectivirgula Kurup and Agre 1983 to the Genus Saccharopolyspora Lacey and Goodfellow 1975, Elevation of Saccharopolyspora hirsuta subsp. taberi Labeda 1987 to Species Level, and Emended Description of the Genus Saccharopolyspora
}

\author{
F. KORN-WENDISCH, ${ }^{1 *}$ A. KEMPF, ${ }^{1}$ E. GRUND, ${ }^{1}$ R. M. KROPPENSTEDT, ${ }^{2}$ AND H. J. KUTZNER ${ }^{1}$ \\ Institut für Mikrobiologie der Technischen Hochschule Darmstadt, D-6100 Darmstadt ${ }^{1}$ and Deutsche Sammlung von \\ Mikroorganismen, D-3300 Braunschweig, ${ }^{2}$ Federal Republic of Germany
}

\begin{abstract}
A thorough taxonomic study of the genera Saccharopolyspora and Faenia showed that both of these taxa can be included in one genus. We propose that Faenia rectivirgula be transferred to the genus Saccharopolyspora Lacey and Goodfellow 1975 as Saccharopolyspora rectivirgula (Kurup and Agre 1983) comb. nov. A description of the new Saccharopolyspora species is presented. The type strain is strain DSM 43747 (= ATCC 33515 ). In addition, we propose that Saccharopolyspora hirsuta subsp. taberi Labeda 1987 strain NRRL B-16 $173^{\mathrm{T}}(\mathrm{T}=$ type strain) be given species status as Saccharopolyspora taberi sp. nov.
\end{abstract}

In 1987 Labeda (30) transferred Streptomyces erythraeus to the genus Saccharopolyspora as Saccharopolyspora erythraea Labeda 1987 comb. nov. on the basis of its cell wall chemistry. Our studies of the genus Streptomyces also indicated that Streptomyces erythraeus did not belong in the genus Streptomyces, since the cell walls contained mesodiaminopimelic acid (DAP) and because of phage typing results (Korn-Wendisch, Ph.D. thesis, Technical University, Darmstadt, Federal Republic of Germany, 1982). Further studies, in which biochemical criteria (DAP and sugar type, as well as menaqinone and fatty acid patterns), were used, confirmed our previous findings (Grund, Ph.D. thesis, Technical University, Darmstadt, Federal Republic of Germany, 1987), but, in contrast to the conclusion of Labeda, we placed this organism in the genus Faenia (12). Recently, Embley et al. (7-9) demonstrated a close relationship among Faenia rectivirgula, Saccharopolyspora erythraea, and Saccharopolyspora hirsuta, which together with Pseudonocardia thermophila form a closely related group of genera having type IV cell walls.

The genus Faenia (26) comprises only one species on the Approved Lists (40), the thermophilic organism Faenia rectivirgula (formerly Micropolyspora rectivirgula [49]; synonym, Micropolyspora faeni [1]), one of the causative agents of farmer's lung disease $(3,25,28,43)$. A mesophilic species, "Faenia interjecta"' (41), has not been validly published and was not available for our studies. The genus Saccharopolyspora currently consists of two species, Saccharopolyspora hirsuta (including Saccharopolyspora hirsuta subsp. taberi) and Saccharopolyspora erythraea (30).

In a detailed study we compared the morphological, physiological, biochemical, and molecular characteristics of 24 strains belonging to the genera Faenia and Saccharopolyspora. Our results strongly suggest that Faenia rectivirgula belongs in the genus Saccharopolyspora and that Saccharopolyspora hirsuta subsp. taberi should be elevated to species status.

\footnotetext{
* Corresponding author.
}

\section{MATERIALS AND METHODS}

Organisms. The origins of the 24 strains used in this study, as well as three reference strains, are shown in Table 1. Cultural characteristics were observed on Trypticase soy agar (TSA) (BBL Microbiology Systems, Cockeysville, Md.) and GYM agar (29), each prepared with and without $5 \%$ $\mathrm{NaCl}$, and on inorganic salts starch agar (48).

Morphology. Light microscopy and scanning electron microscopy were performed as described by Greiner-Mai et al. (14).

Biochemical markers. The isomer of DAP and the sugars in whole-cell hydrolysates were identified by using the methods of Becker et al. (2) and Lechevalier and Lechevalier (36), as modified by Stanek and Roberts (50) for separation on thin-layer plates. The acyl type of the cell wall was analyzed by using the method of Uchida and Aida (51). The occurrence of mycolic acids was determined by using the methods of Minnikin et al. (38). Phospholipids were extracted and identified by using the methods of Minnikin et al. (39). Menaquinones were extracted and purified as described by Collins et al. (5) and were identified by high-performance liquid chromatography $(21,22)$.

Fatty acid analysis was performed as described below. Cultures were grown for 2 days on Trypticase soy broth at $40^{\circ} \mathrm{C}$ on a rotary shaker $(160 \mathrm{rpm})$. The cells were harvested by filtration, and about $50 \mathrm{mg}$ of wet cells was transferred to a screw-cap tube $(13$ by $100 \mathrm{~mm}$; the cap was fitted with a teflon insert). After $1-\mathrm{ml}$ portions of $50 \%$ aqueous methanol containing $15 \% \mathrm{NaOH}$ were added, the tubes were heated for $30 \mathrm{~min}$ in a boiling water bath and then cooled to room temperature. The sodium salts of the fatty acids were methylated by adding $2 \mathrm{ml}$ of a hydrochloric acid-methanol mixture $(325 \mathrm{ml}$ of $6 \mathrm{~N}$ hydrochloric acid and $275 \mathrm{ml}$ of methanol) and kept for $10 \mathrm{~min}$ at $80^{\circ} \mathrm{C}$. The methyl esters were extracted with $1.25 \mathrm{ml}$ of hexane:tert-butyl-methylether $(1: 1, \mathrm{vol} / \mathrm{vol})$. The phases were separated by centrifugation, and the aqueous layer was removed with a Pasteur pipette and discarded. The nonmethylated fatty acids and other polar substances were eliminated from the organic phase by shaking with $3 \mathrm{ml}$ of $1.2 \% \mathrm{NaOH}$. For phase separation the samples were centrifuged, and one-half of the upper organic phase containing the fatty acid methyl esters was transferred to a septum-capped vial for subsequent 
TABLE 1. Strains belonging to the genus Saccharopolyspora and related genera (cell wall type IV) used in this study

\begin{tabular}{|c|c|c|c|c|}
\hline Species & $\operatorname{Strain}(s)^{a}$ & $\begin{array}{l}\text { DSM } \\
\text { No. }^{a}\end{array}$ & Previous name & Provided by: \\
\hline Saccharopolyspora hirsuta & $\begin{array}{l}\text { A1143 }^{\mathrm{T}} \\
\text { A1143 } \\
\text { NRRL B-5792 }^{\mathrm{T}} \\
\text { IMRU 1558 } \\
\text { IMRU 1461 } \\
\text { GP1, GP2 }\end{array}$ & $\begin{array}{l}43402 \\
43401\end{array}$ & $\begin{array}{l}\text { Saccharopolyspora hirsuta } \\
\text { Saccharopolyspora hirsuta } \\
\text { Saccharopolyspora hirsuta } \\
\text { Saccharopolyspora hirsuta } \\
\text { Saccharopolyspora hirsuta } \\
\text { Saccharopolyspora } \text { sp. }\end{array}$ & $\begin{array}{l}\text { J. Lacey } \\
\text { G. Vobis } \\
\text { R. Brzezinski }\left(=\mathrm{A} 1143^{\mathrm{T}}\right) \\
\text { R. E. Gordon } \\
\text { R. E. Gordon } \\
\text { Our isolates }\end{array}$ \\
\hline Saccharopolyspora taberi & NRRL B-16173 ${ }^{\mathrm{T}}$ & $43856^{T}$ & $\begin{array}{l}\text { Saccharopolyspora hirsuta } \\
\text { subsp. taberi }\end{array}$ & D. P. Labeda \\
\hline Saccharopolyspora erythraea & 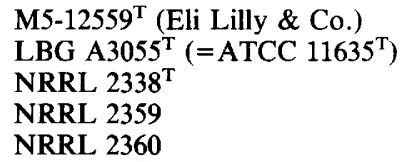 & $\begin{array}{l}40517^{\mathrm{T}} \\
40517 \mathrm{e}^{\mathrm{T}}\end{array}$ & $\begin{array}{l}\text { Streptomyces erythraeus } \\
\text { Streptomyces erythraeus } \\
\text { Streptomyces erythraeus } \\
\text { Streptomyces erythraeus } \\
\text { Streptomyces erythraeus }\end{array}$ & $\begin{array}{l}\left.\text { E. B. Shirling (= ISP } 5517^{\mathrm{T}}\right) \\
\text { L. Ettlinger } \\
\text { R. Brzezinski } \\
\text { R. Brzezinski } \\
\text { R. Brzezinski }\end{array}$ \\
\hline Saccharopolyspora rectivirgula & $\begin{array}{l}\text { INMI 683 }{ }^{\mathrm{T}} \text { (N.S. Agre) } \\
\text { K1325 } \\
\text { A94 (J. Lacey) } \\
\text { T-150 (= A94) } \\
\text { A1313 (J. Lacey) } \\
\text { G9, MK31, R3y, TG2, TD7, } \\
\text { TF15 }\end{array}$ & $\begin{array}{l}43747^{\mathrm{T}} \\
43755 \\
43113 \\
43371 \\
43114\end{array}$ & $\begin{array}{l}\text { Faenia rectivirgula } \\
\text { Micropolyspora rectivirgula } \\
\text { Micropolyspora faeni } \\
\text { Micropolyspora faeni } \\
\text { Micropolyspora faeni } \\
\text { Faenia sp. }\end{array}$ & $\begin{array}{l}\text { N. S. Agre } \\
\text { H. Prauser, IMET } \\
\text { J. Lacey } \\
\text { V. P. Kurup } \\
\text { J. Lacey } \\
\text { Our isolates }^{b}\end{array}$ \\
\hline $\begin{array}{l}\text { Pseudonocardia thermophila } \\
\text { Saccharomonospora viridis } \\
\text { Amycolatopsis azurea }\end{array}$ & $\begin{array}{l}\text { KCC A-0032 } \\
\text { P101 } \\
\text { S. Omura AM-3696 }\end{array}$ & $\begin{array}{l}43027 \\
43017^{\mathrm{T}} \\
43854^{\mathrm{T}}\end{array}$ & $\begin{array}{l}\text { Pseudonocardia thermophila } \\
\text { Saccharomonospora viridis } \\
\text { Pseudonocardia azurea }\end{array}$ & $\begin{array}{l}\text { A. Seino } \\
\text { E. Küster } \\
\text { A. Henssen }\end{array}$ \\
\hline
\end{tabular}

${ }^{a} \mathrm{~T}=$ type strain cited on the Approved Lists of Bacterial Names (40, 49). ATCC, American Type Culture Collection, Rockville, Md.; DSM, Deutsche Sammlung von Mikroorganismen, Braunschweig, Federal Republic of Germany; IMET, Institute of Microbiology and Experimental Therapy, Jena, German Democratic Republic; IMRU, Institute of Microbiology, Rutgers University, New Brunswick, N.J.; INMI, Institute for Microbiology, USSR Academy of Sciences, Moscow, USSR; KCC, Kaken Chemical Company, Ltd., Tokyo, Japan; NRRL, Northern Regional Research Center, Agricultural Research Service, U.S. Department of Agriculture, Peoria, Ill.

${ }^{b}$ Strains isolated in our laboratory from moldy hay, soil, compost, and manure.

analysis by automated gas-liquid chromatography in which a model HP5898A microbial identification system (HewlettPackard Co., Avondale, Pa.) was used. This system included a model $5890 \mathrm{~A}$ gas chromatograph equipped with a hydrogen flame ionization detector, an automatic injector, a sample controller, and a sample tray, as well as an electronic integrator controlled by a microcomputer. The gas chromatograph contained a fused silica capillary column (length, $25 \mathrm{~m}$; inside diameter, $0.25 \mathrm{~mm}$ ) that was cross-linked with methylphenyl silicone (SE4) as the stationary phase. The following computer-controlled parameters were set for the instrument: injector temperature, $250^{\circ} \mathrm{C}$; detector temperature, $300^{\circ} \mathrm{C}$; oven temperature, programmed to increase from 170 to $300^{\circ} \mathrm{C}$ at a rate of $5^{\circ} \mathrm{C} / \mathrm{min}$ and held at $300^{\circ} \mathrm{C}$ for $1 \mathrm{~min}$ before recycling to the initial temperature. The cellular fatty acid methyl esters were identified by comparing retention times with retention times of known standards and by computer calculation of equivalent chain lengths. The software for the numerical analysis and for the construction of the dendrogram was obtained from Microbial ID, Inc., Newmark, Del.

DNA base composition. Deoxyribonucleic acid (DNA) was isolated by a modified phenol method (42) by using ribonuclease $A$ together with ribonuclease $T_{1}$. The guanine-pluscytosine $(\mathrm{G}+\mathrm{C})$ content of DNA was determined by highperformance liquid chromatography (52).

Physiological properties. To determine the optimum temperature for growth, slants of GYM agar and TSA were inoculated with $0.05-\mathrm{ml}$ portions of a spore suspension and incubated at $20,28,37,42,45,50,55,60$, and $65^{\circ} \mathrm{C}$. Growth was observed after 3,5 , and 10 days. All of the other tests were then carried out at the optimum temperature for each individual strain (see below).

The following physiological tests were performed by using previously described methods: formation of melanin (14); resistance toward lysozyme and sodium chloride (27); hydrolysis of esculin, arbutin, urea, and allantoin (29), with final concentrations of $\beta$-glycosides, urea, and allantoin of $0.1,1$, and $1 \%$, respectively; hemolysis and egg yolk reaction (29); utilization of carbohydrates as sole carbon sources (48); and antibiotic activity (using the streak test on cornsteep agar plates [29]) against Escherichia coli, Pseudomonas aeruginosa, Staphylococcus aureus, Bacillus cereus, Mucor ramannianus, Candida albicans, and Geotrichum candidum.

The ability to decompose adenine, xanthine, hypoxanthine, and tyrosine was determined by using TSA as the basal medium and the appropriate substrates at concentrations of $0.5 \%$. The ability to degrade macromolecules was determined by using nutrient agar as the basal medium and adding the following substrates: gelatin (1.0\%), elastin (elastin-congo red [Sigma Chemical Co., St. Louis, Mo.], 0.2\%), starch $(1.5 \%)$, chitin $(0.4 \%)$, prepared as described by $\mathrm{Hsu}$ and Lockwood [18]), and xylan (0.4\%). The degradation of casein and DNA were tested by using calcium caseinate agar (catalog no. 5409; E. Merck AG, Darmstadt, Federal Republic of Germany) and deoxyribonuclease test agar (catalog no. 152-1580; GIBCO Laboratories, Grand Island, N.Y.), respectively.

Phage typing. The phage typing tests were carried out as described by Korn et al. (20) and Kempf et al. (19). The following set of phages was used (47): three phages isolated with Saccharopolyspora erythraea, five virulent phages isolated with Saccharopolyspora rectivirgula, 15 temperate phages isolated from soil and lysogenic strains of Saccharopolyspora rectivirgula, and $\phi \mathrm{SaG1}$, a Saccharomonospora phage isolated from soil.

Enzyme and protein patterns. Analyses of esterases, malate dehydrogenase, and total proteins were performed by using the methods described by Greiner-Mai et al. (13). 
TABLE 2. Cultural and morphological characteristics of the four Saccharopolyspora species ${ }^{a}$

\begin{tabular}{|c|c|c|c|c|c|}
\hline Species & $\begin{array}{l}\text { No. of } \\
\text { strains } \\
\text { tested }\end{array}$ & $\begin{array}{l}\text { Color of substrate } \\
\text { mycelium }\end{array}$ & $\begin{array}{l}\text { Color of aerial } \\
\text { mycelium }\end{array}$ & $\begin{array}{l}\text { Morphology of } \\
\text { aerial mycelium }\end{array}$ & $\begin{array}{l}\text { Morphology of } \\
\text { spores }\end{array}$ \\
\hline Saccharopolyspora hirsuta & 7 & Colorless to orange & White & $\begin{array}{l}\text { Straight to loose } \\
\text { spirals }\end{array}$ & Smooth to hairy \\
\hline Saccharopolyspora taberi & 1 & $\begin{array}{l}\text { Yellow to orangish red to } \\
\text { brownish red }\end{array}$ & No aerial mycelium & & \\
\hline Saccharopolyspora erythraea & 5 & $\begin{array}{l}\text { Light brown to orangish red, } \\
\text { violet, or brownish red }\end{array}$ & Pinkish red (cinnamon) & Open spirals & Spiny \\
\hline Saccharopolyspora rectivirgula & 11 & Yellow to orange & White to light pink & Straight & Smooth to roughened \\
\hline
\end{tabular}

${ }^{a}$ Cultural characteristics were observed on TSA and GYM agar supplemented with $5 \% \mathrm{NaCl}$, as well as on inorganic salts starch agar.

Occurrence of plasmids and restriction analysis of total DNA. Organisms were grown for 24 to $36 \mathrm{~h}$ in modified YEME broth (17), which contained $10.3 \%$ sucrose, $1 \%$ glucose, $0.3 \%$ yeast extract, $0.3 \%$ malt extract, $0.5 \%$ peptone from casein, and 0 to $0.1 \%$ glycine ( $\mathrm{pH}$ 7.2). After autoclaving, $2 \mathrm{ml}$ of a $2.5 \mathrm{M} \mathrm{MgCl}_{2}$ solution was added per liter. The mycelium was harvested by centrifugation, washed with W1 solution [10 mM tris(hydroxymethyl)aminomethane, $1 \mathrm{mM}$ ethylenediaminetetraacetate, $15 \%$ sucrose], and stored at $-20^{\circ} \mathrm{C}$. Plasmid DNA and total DNA were isolated by using the rapid methods of Hopwood et al. (17) with the following two modifications: (i) addition of only $1 \mathrm{mg}$ of lysozyme (grade I; Sigma) per $\mathrm{ml}$, and (ii) the incubation time in the lysozyme solution at $37^{\circ} \mathrm{C}$ was varied from 0.5 to $5 \mathrm{~min}$ depending on the strain investigated. For restriction of the total DNA the enzymes $B g l \mathrm{II}$ and BstEII were used. Electrophoresis was carried out as described by Greiner-Mai et al. (13).

\section{RESULTS}

As shown in Table 1, many of the strains which we investigated were described and received under various names. In order to avoid confusion, below we use the new names which we propose in this paper.

Cultural characteristics. The colors of the substrate mycelia of the four species varied from colorless to yellowish orange to reddish, violet, or brownish red on the three media tested (GYM agar, inorganic salts starch agar, and TSA) (Table 2). The color of the aerial mycelia of Saccharopolyspora hirsuta and Saccharopolyspora rectivirgula was white on GYM agar and TSA supplemented with $5 \% \mathrm{NaCl}$; in contrast, Saccharopolyspora erythraea produced pinkish red aerial mycelium, while Saccharopolyspora taberi produced no aerial mycelium.

Morphology. The spore chains of Saccharopolyspora hirsuta were straight or in loose spirals (Table 2). Young cultures ( 3 to 7 days old) produced smooth spores (Fig. 1a); spores with tufts of hairs, like those described by Lacey and Goodfellow (33), were observed only after prolonged incubation (17 days) (Fig. 1b). No aerial mycelium was observed macroscopically in Saccharopolyspora taberi; electron microscopy revealed fragmenting hyphae on the surface of the substrate mycelium (Fig. 1c). Saccharopolyspora erythraea produced aerial mycelium with spore chains consisting of open loops or loose spirals; the spores had spiny ornamentation (Fig. 1d). In contrast, Saccharopolyspora rectivirgula produced spores in short straight chains, and the spore surfaces were rough (Fig. 1e).

Chemotaxonomic markers. The biochemical properties are summarized in Table 3 . All of the strains belonging to the genus Saccharopolyspora contained meso-DAP, $N$-acetylmuramic acid, and sugar type A (i.e., cell wall type IV sensu Lechevalier and Lechevalier [36]). No mycolic acids were found in any strain tested. Iso- and anteiso-branched fatty acids were found together with straight-chain fatty acids. Moreover, small amounts of 10-methyl branched fatty acids were detected in strains of all four Saccharopolyspora species. These results are in accordance with the results of Hofheinz and Grisebach (16) for Streptomyces erythraeus and of Embley et al. (7) for Saccharopolyspora erythraea and Saccharopolyspora hirsuta. All of the strains produced similar phospholipid patterns with phosphatidylglycerol, diphosphatidylglycerol, phosphatidylinositol, and several ninhydrin-positive phospholipids. These phospholipids were identified by using their straining properties and their $\boldsymbol{R}_{f}$ values as phosphatidylethanolamine, lysophosphatidylethanolamine, and phosphatidylmethylethanolamine. Phosphatidylcholine, which was identified by its $R_{f}$ value and staining properties, was the diagnostic phospholipid in all four species (35). Several glycolipids were found in all strains; one of these glycolipids was characteristic for the genus. In addition, Saccharopolyspora hirsuta contained hydroxyphosphatidylethanolamine. The main menaquinone (55 to 80\%) in all four species was MK-9( $\left.\mathrm{H}_{4}\right)$. In addition, Saccharopolyspora hirsuta contained $\mathrm{MK}-9\left(\mathrm{H}_{2}\right)(30$ to $40 \%$ ) and small amounts of MK-9( $\left.\mathbf{H}_{0}\right)$. In contrast, Saccharopolyspora rectivirgula, Saccharopolyspora erythraea, and Saccharopolyspora taberi contained considerable amounts of $\mathrm{MK}-10\left(\mathrm{H}_{4}\right)$ (20 to $30 \%$ ), as well as small amounts of $\mathrm{MK}-9\left(\mathrm{H}_{2}\right)$ and MK-9 $\left(\mathrm{H}_{6}\right)(2$ to $10 \%)$. The $\mathrm{G}+\mathrm{C}$ contents of the DNAs of the four species were very similar (70.4 to $71.5 \mathrm{~mol} \%)$. Differences in $\mathrm{G}+\mathrm{C}$ content reported previously $(37,44)$ for Saccharopolyspora rectivirgula and Saccharopolyspora hirsuta are due to the use of different methods for determination.

As Table 3 shows, the four Saccharopolyspora species could be separated from three other genera of organisms having mycolateless cell walls. Pseudonocardia thermophila possessed small amounts of anteiso-branched fatty acids and contained only one saturated menaquinone, $\mathrm{MK}-8\left(\mathrm{H}_{4}\right)$. Neither phosphatidylcholine nor 10-methyl branched fatty acids were found in Saccharomonospora viridis and Amycolatopsis azurea. Moreover, the combination of the tetrahydrogenated menaquinones MK-9 $\left(\mathrm{H}_{4}\right)$ and $\mathrm{MK}-8\left(\mathrm{H}_{4}\right)$ was characteristic for the genus Saccharomonospora, while Amycolatopsis azurea also contained MK- $9\left(\mathrm{H}_{4}\right)$ and significant amounts of MK- $9\left(\mathrm{H}_{2}\right)$.

The dendrogram in Fig. 2 shows the relationships among strains belonging to the genus Saccharopolyspora based on their fatty acid compositions, which are given in detail in Table 4. As Fig. 2 shows, the strains of Saccharopolyspora 

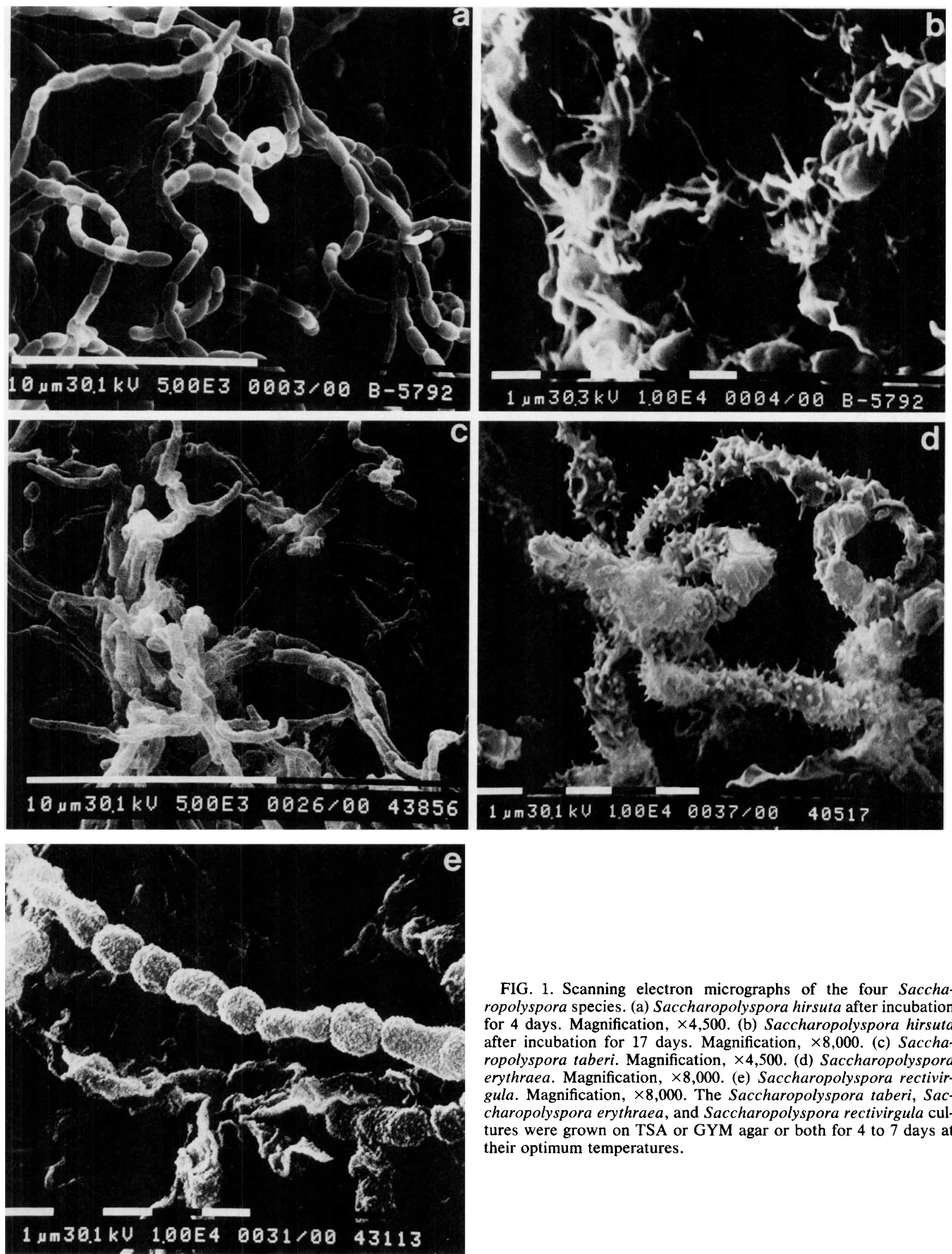

FIG. 1. Scanning electron micrographs of the four Saccharopolyspora species. (a) Saccharopolyspora hirsuta after incubation for 4 days. Magnification, $\times 4,500$. (b) Saccharopolyspora hirsuta after incubation for 17 days. Magnification, $\times 8,000$. (c) Saccharopolyspora taberi. Magnification, $\times 4,500$. (d) Saccharopolyspora erythraea. Magnification, $\times 8,000$. (e) Saccharopolyspora rectivirgula. Magnification, $\times 8,000$. The Saccharopolyspora taberi, Saccharopolyspora erythraea, and Saccharopolyspora rectivirgula cultures were grown on TSA or GYM agar or both for 4 to 7 days at their optimum temperatures. 
TABLE 3. Chemical markers of the four Saccharopolyspora species and related organisms

\begin{tabular}{|c|c|c|c|c|c|c|c|c|}
\hline Property & $\begin{array}{l}\text { Methods used } \\
\text { described in } \\
\text { reference(s): }\end{array}$ & $\begin{array}{l}\text { Saccharopoly- } \\
\text { spora hirsuta } \\
(n=7)^{a}\end{array}$ & $\begin{array}{l}\text { Saccharopoly- } \\
\text { spora taberi } \\
(n=1)\end{array}$ & $\begin{array}{c}\text { Saccharopoly- } \\
\text { spora eryth- } \\
\text { raea } \\
(n=5)\end{array}$ & $\begin{array}{l}\text { Saccha- } \\
\text { ropolyspora } \\
\text { rectivirgula } \\
(n=11)\end{array}$ & $\begin{array}{l}\text { Pseudono- } \\
\text { cardia ther- } \\
\text { mophila } \\
\quad(n=1)\end{array}$ & $\begin{array}{l}\text { Saccha- } \\
\text { romono- } \\
\text { spora viridis } \\
(n=1)\end{array}$ & $\begin{array}{l}\text { Amycolatop- } \\
\text { sis azurea } \\
(n=1)\end{array}$ \\
\hline DAP isomer & 36,50 & meso & meso & meso & meso & meso & meso & meso \\
\hline Acyl type ${ }^{b}$ & 51 & NAcM & NAcM & NAcM & NAcM & NAcM & NAcM & NAcM \\
\hline Sugar type ${ }^{c}$ & 36,50 & A & A & A & A & A & A & A \\
\hline Mycolic acids $^{d}$ & 38 & - & - & - & - & - & - & - \\
\hline Phospholipids $^{d, e}$ & 39 & & & & & & & \\
\hline PC & & + & + & + & + & + & - & - \\
\hline $\mathrm{PE}$ & & + & + & $(+)$ & $(+)$ & + & + & + \\
\hline lyso-PE & & + & + & + & + & + & + & - \\
\hline OPE & & + & - & - & - & + & + & + \\
\hline PG & & + & + & + & + & + & - & + \\
\hline DPG & & + & + & + & + & + & + & + \\
\hline PME & & + & + & + & + & - & - & - \\
\hline PI & & + & + & + & + & + & + & + \\
\hline \multicolumn{9}{|l|}{ Fatty acids $s^{f}$} \\
\hline Saturated & & + & $(+)$ & ++ & + & $(+)$ & ++ & ++ \\
\hline Unsaturated & & - & - & $(+)$ & $(+)$ & $(+)$ & $(+)$ & - \\
\hline Iso- $16 / 18$ & & ++ & ++ & ++ & ++ & ++ & +++ & ++ \\
\hline Iso- $15 / 17$ & & ++ & ++ & ++ & ++ & ++ & + & ++ \\
\hline Anteiso-15/17 & & ++ & ++ & ++ & ++ & + & $(+)$ & + \\
\hline 10-Methyl & & (v) & + & $(+)$ & + & $\operatorname{tr}$ & - & - \\
\hline $\mathrm{OH}-\mathrm{FA}$ & & $(+)$ & - & - & - & + & + & + \\
\hline Menaquinones $^{g}$ & $5,21,22$ & & & & & & & \\
\hline $8 / 4$ & & - & - & - & - & +++ & ++ & $(+)$ \\
\hline $9 / 0$ & & + & - & - & - & - & - & - \\
\hline $9 / 2$ & & ++ & + & + & + & - & - & ++ \\
\hline $9 / 4$ & & +++ & +++ & +++ & +++ & - & $+t+$ & +++ \\
\hline $9 / 6$ & & - & - & - & + & - & - & - \\
\hline $10 / 4$ & & - & $+t$ & ++ & ++ & - & - & - \\
\hline $\mathrm{G}+\mathrm{C}$ content $(\mathrm{mol} \%)$ & 42,52 & 71.5 & 70.8 & 71.1 & 70.4 & $79.0^{h}$ & $74-75^{h}$ & $66.0^{h}$ \\
\hline
\end{tabular}

${ }^{a} n$ is the number of strains tested.

${ }^{b}$ NAcM, $N$-acetylmuramic acid.

${ }^{c}$ Sugar type A: arabinose plus galactose. In addition, glucose and ribose were found.

${ }^{d}+$, Present; - , absent; $(+)$, present in only trace amounts.

$e$ Abbreviations: PC, phosphatidylcholine; PE, phosphatidylethanolamine; lyso-PE, lysophosphatidylethanolamine; OPE, hydroxyphosphatidylethanolamine; PG, phosphatidylglycerol; DPG, diphosphatidylglycerol; PME, phosphatidylmethylethanolamine; PI, phosphatidylinositol.

$f-$, Absent $(+),<5 \% ;+, 5$ to $14 \% ;++, 15$ to $49 \% ;+++,>50 \% ;(v)$, variable; tr, trace. The following examples illustrate the abbreviations used for fatty acids: iso-15, 13-methyltetradecanoic acid; anteiso-15, 12-methyltetradecanoic acid. OH-FA, 2-Hydroxy fatty acids.

$g$-, Absent; $(+),<5 \% ;+, 5$ to $14 \% ;++, 15$ to $49 \% ;+++,>50 \%$. The following example illustrates the abbreviations used for menaquinones: $9 / 4$, 2-methyl-II,III-tetra-hydronona-prenyl-1,4-naphthoquinone (4).

${ }^{h}$ Data from references 11 and 15.

rectivirgula form as heterogeneous a cluster as the second cluster, which comprises the other three Saccharopolyspora species. However, the data in Table 4 reveal that some fatty acids exhibited an overlapping distribution that is not in accordance with the two main clusters; iso-14:0 and cis917:1 acids occurred in Saccharopolyspora rectivirgula and Saccharopolyspora erythraea, and hydroxy fatty acids occurred only in Saccharopolyspora hirsuta. While 16:0 acid was found in all of the strains except Saccharopolyspora rectivirgula strains, 15:1, iso-16:1, and iso-17:1 acids were limited to this species. Saccharopolyspora erythraea contained a remarkably high amount of 17:0 acid. These findings were in general agreement with those of Embley et al. (6); the main fatty acids synthesized by all strains were iso-15:0, iso-16:0, iso-17:0, and anteiso-17:0 acids. Different results were obtained for some minor fatty acids, and two of these acids, iso-10meth-16:0 acid and iso-10meth-17:0 acid (10), deserve mentioning; these acids were found originally in Saccharopolyspora hirsuta (10) and later in Saccharopolyspora rectivirgula and Saccharopolyspora erythraea (7). In our investigation these two fatty acids were limited to a few strains of Saccharopolyspora rectivirgula (more strains contained the precursor fatty acids iso-16:1 and iso-17:1 acids), and iso-10meth-17:0 acid was also found in Saccharopolyspora taberi. This was due to differences in culture conditions and sample preparation $(7,10,24)$.

Physiology. We tested a large number of physiological properties of all strains of the four Saccharopolyspora species (Table 5); however, differences were found only in the temperature range for growth, growth in the presence of $\mathrm{NaCl}$, production of antibiotics, and some degradative activities. The thermophilic organism Saccharopolyspora rectivirgula grew at temperatures ranging from 37 to $60^{\circ} \mathrm{C}$ (but not at $65^{\circ} \mathrm{C}$ ) and at $\mathrm{NaCl}$ concentrations up to $10 \%$. The strains of Saccharopolyspora hirsuta were moderately thermophilic, growing at temperatures ranging from 20 to $50^{\circ} \mathrm{C}$ and at $\mathrm{NaCl}$ concentrations up to $7 \%$. In contrast, Saccharopolyspora erythraea and Saccharopolyspora taberi were mesophilic, growing at temperatures ranging from 20 to $45^{\circ} \mathrm{C}$. Also, Saccharopolyspora erythraea grew at $\mathrm{NaCl}$ concentrations only up to 5\%, and Saccharopolyspora taberi grew at $\mathrm{NaCl}$ concentrations up to $7 \%$. Furthermore, all strains of Saccharopolyspora erythraea produced erythromycins and showed activity against gram-positive and gramnegative bacteria; strains of Saccharopolyspora hirsuta exhibited antibiotic activity against Bacillus cereus. 


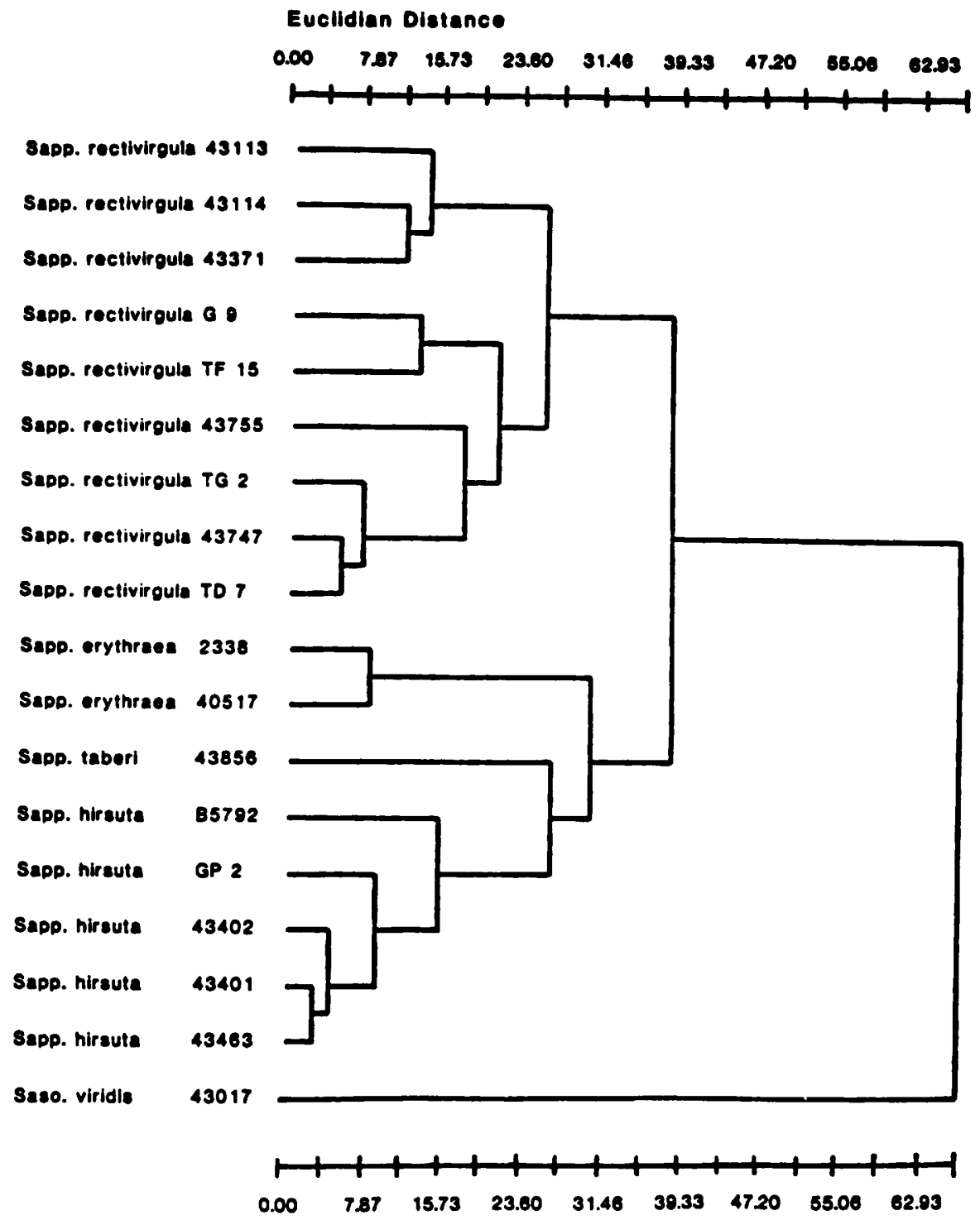

FIG. 2. Dendrogram showing the relationships among strains of Saccharopolyspora species, as well as the type strain of Saccharomonospora viridis, based on fatty acid analysis. Data for a matrix of Euclidian distances were computed and were subjected to a cluster analysis (unweighted pair group method with arithmetic average). Sapp., Saccharopolyspora; Saso., Saccharomonospora.

The four Saccharopolyspora species were lysozyme sensitive, did not produce melanoid pigment on complex and synthetic media, and did not exhibit an egg yolk reaction and hemolysis. All strains hydrolyzed esculin, arbutin, urea, allantoin, and uric acid and degraded xanthine, hypoxanthine, gelatin, and casein but not xylan. Differences were found in degradation of adenine, tyrosine, elastin, starch, chitin, and DNA. Glucose, xylose, fructose, sucrose, raffinose, mannitol, and inositol were utilized as sole carbon sources, but L-arabinose was not. Rhamnose and lactose were poor substrates, and the results with these compounds were often equivocal.

Phage typing. The host ranges of the actinophages clearly showed that all four species belong in one genus (Table 6). All three phages of Saccharopolyspora erythraea lysed Saccharopolyspora taberi and the nonlysogenic strains of Saccharopolyspora rectivirgula. The five virulent phages of Saccharopolyspora rectivirgula were species specific, lysing all strains of Saccharopolyspora rectivirgula but none of the other species. The 15 temperate phages formed the following two groups: (i) 11 phages lysed only the nonlysogenic strains of Saccharopolyspora rectivirgula; and (ii) the other 4 phages were genus specific (i.e., these phages lysed strains of all four Saccharopolyspora species). However, plaques on Saccharopolyspora hirsuta were observed only when high phage titers were used, perhaps suggesting a restrictionmodification barrier (J. Schneider, personal communication). On the other hand, none of these phages produced plaques on Pseudonocardia thermophila or on strains of Saccharomonospora species. Similarly, the Saccharomonospora phage $\phi \mathrm{SaG} 1$ did not lyse any Saccharopolyspora species.

Enzyme patterns. We identified four different esterase patterns, which corresponded to the four Saccharopolyspora species (Fig. 3 and 4a). Saccharopolyspora hirsuta (seven strains) had the strongest bands at $R_{f}$ values of 0.34 and 0.57; Saccharopolyspora taberi had bands at $R_{f}$ values of $0.32,0.63$, and 0.68; Saccharopolyspora erythraea (five 


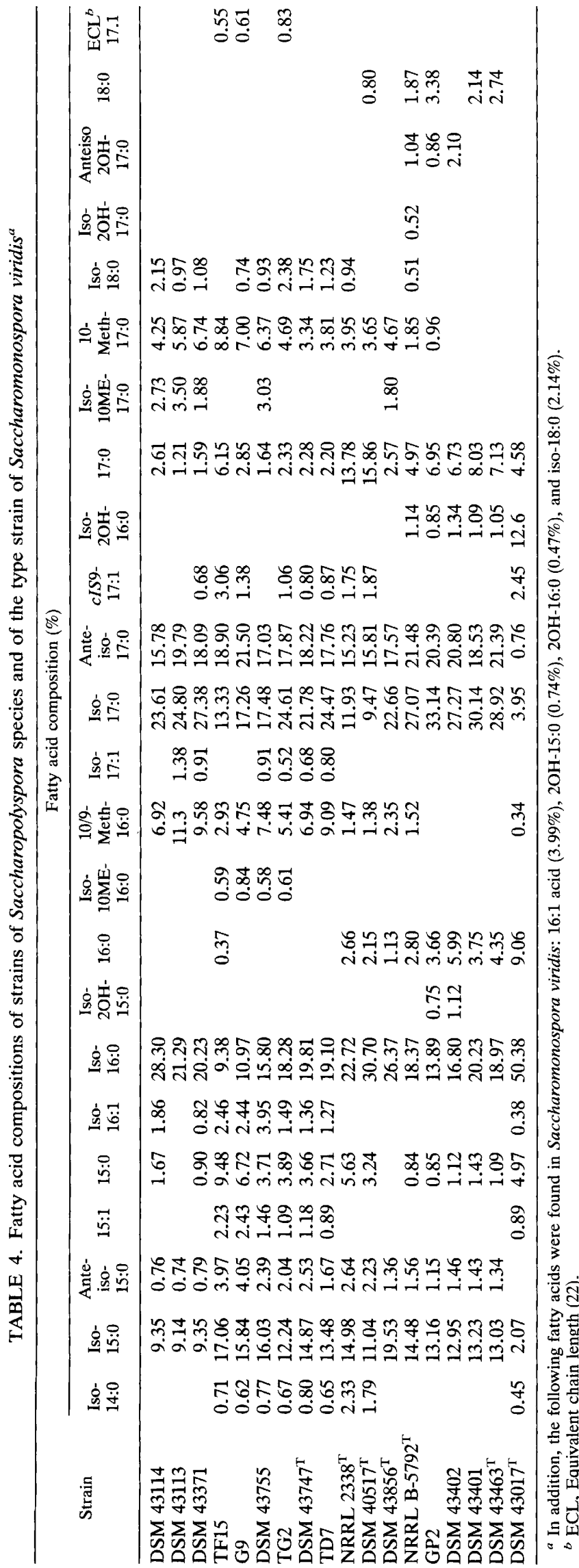

TABLE 5. Physiological properties of the four Saccharopolyspora species

\begin{tabular}{|c|c|c|c|c|}
\hline Property & $\begin{array}{c}\text { Saccharo- } \\
\text { polyspora } \\
\text { hirsuta } \\
(n=7)^{a}\end{array}$ & $\begin{array}{c}\text { Saccharo- } \\
\text { polyspora } \\
\text { taberi } \\
(n=1)\end{array}$ & $\begin{array}{c}\text { Saccharo- } \\
\text { polyspora } \\
\text { erythraea } \\
(n=5)\end{array}$ & $\begin{array}{c}\text { Saccharopoly- } \\
\text { spora recti- } \\
\text { virgula } \\
(n=11)\end{array}$ \\
\hline \multicolumn{5}{|l|}{ Growth at ${ }^{b}$ : } \\
\hline $20^{\circ} \mathrm{C}$ & + & + & + & - \\
\hline $28^{\circ} \mathrm{C}$ & ++ & ++ & ++ & - \\
\hline $37^{\circ} \mathrm{C}$ & $+t$ & $+++^{c}$ & $+++^{c}$ & + \\
\hline $42^{\circ} \mathrm{C}$ & $++t^{c}$ & + & ++ & $+t$ \\
\hline $45^{\circ} \mathrm{C}$ & +++ & + & Weak & +++ \\
\hline $50^{\circ} \mathrm{C}$ & $+t$ & - & - & $+++^{c}$ \\
\hline $55^{\circ} \mathrm{C}$ & - & - & - & +++ \\
\hline $60^{\circ} \mathrm{C}$ & - & - & - & + \\
\hline \multicolumn{5}{|l|}{ Growth on: } \\
\hline $4 \% \mathrm{NaCl}$ & + & + & + & + \\
\hline $7 \% \mathrm{NaCl}$ & + & $(+)^{d}$ & - & + \\
\hline $10 \% \mathrm{NaCl}$ & - & - & - & + \\
\hline \multicolumn{5}{|c|}{ Degradation of: } \\
\hline Adenine & + & + & + & - \\
\hline Xanthine & $(+)$ & $(+)$ & + & $(+)$ \\
\hline Tyrosine & $(+)$ & + & + & $(+)$ \\
\hline Elastin & + & + & + & - \\
\hline Starch & + & + & + & - \\
\hline Chitin & + & + & + & - \\
\hline DNA & + & - & + & - \\
\hline \multicolumn{5}{|l|}{ Utilization of: } \\
\hline Xylose & $(+)$ & + & + & + \\
\hline Rhamnose & $(+)$ & $(+)$ & $(+)$ & $v^{e}$ \\
\hline Lactose & $\mathrm{v}$ & $(+)$ & $(+)$ & $(+)$ \\
\hline Sucrose & + & $(+)$ & + & + \\
\hline Raffinose & + & + & + & $(+)$ \\
\hline
\end{tabular}

${ }^{a} n$ is the number of strains tested.

$b$ The temperature ranges for growth were determined by using TSA and GYM agar.

${ }^{c}$ Temperature selected for all other physiological tests.

${ }^{d}(+)$, Moderate reaction.

$e \mathrm{v}$, Variable.

strains) had bands at $R_{f}$ values of 0.27 and 0.67 ; and Saccharopolyspora rectivirgula (11 strains) had bands at $R_{f}$ values of $0.27,0.43$, and 0.68 . The analysis of malate dehydrogenases revealed similar, but distinct, $R_{f}$ values for the four species (Fig. 4b). The patterns of total proteins (Fig. 5) also showed four patterns corresponding to the four Saccharopolyspora species.

Restriction analysis of total DNA and occurrence of plasmids. The restriction analysis with BglII clearly showed homogeneity within the strains of each species; each species exhibited a characteristic fingerprint (Fig. 6). We found four strains which harbored plasmids; Saccharopolyspora taberi had one plasmid (>20 kilobases), Saccharopolyspora erythraea NRRL 2359 had one plasmid (>20 kilobases), Saccharopolyspora rectivirgula $\mathrm{R} 3 \mathrm{y}$ had one plasmid ( $>20$ kilobases), and Saccharopolyspora rectivirgula DSM 43114 had several plasmids, which ranged in size from 4 to $>50$ kilobases (J. Schneider, unpublished data).

\section{DISCUSSION}

The genera Saccharopolyspora and Faenia belong to the micropolyspora group (11), a group of sporoactinomycetes that contain meso-DAP, sugar type A with arabinose and galactose, and no mycolic acids in their cell walls (cell wall type IV). Recently, the family Pseudonocardiaceae was established by Embley et al. (9) based on partial sequencing of $16 \mathrm{~S}$ ribosomal ribonucleic acid in which reverse tran- 
TABLE 6. Phage typing of the strains of Saccharopolyspora species

\begin{tabular}{|c|c|c|c|c|c|c|}
\hline \multirow{3}{*}{$\begin{array}{l}\text { No. of } \\
\text { phages }\end{array}$} & \multirow{3}{*}{$\begin{array}{c}\text { Repre- } \\
\text { sentative } \\
\text { phage }\end{array}$} & \multicolumn{5}{|c|}{ Lysis of: } \\
\hline & & \multirow{2}{*}{$\begin{array}{c}\text { Saccharo- } \\
\text { polyspora } \\
\text { hirsuta } \\
(n=7)^{a}\end{array}$} & \multirow{2}{*}{$\begin{array}{c}\text { Saccharo- } \\
\text { polyspora } \\
\text { taberi } \\
(n=1)\end{array}$} & \multirow{2}{*}{$\begin{array}{c}\text { Saccharo- } \\
\text { polyspora } \\
\text { erythraea } \\
(n=5)\end{array}$} & \multicolumn{2}{|c|}{$\begin{array}{l}\text { Saccharopolyspora } \\
\text { rectivirgula }\end{array}$} \\
\hline & & & & & $\begin{array}{l}\text { Non lyso- } \\
\text { genic } \\
\text { strains } \\
(n=8)\end{array}$ & $\begin{array}{c}\text { Lysogenic } \\
\text { strains } \\
(n=3)\end{array}$ \\
\hline
\end{tabular}

\begin{tabular}{|c|c|c|c|c|c|c|}
\hline $3^{b}$ & P517 & - & + & + & + & - \\
\hline $5^{b}$ & P113 & - & - & - & + & + \\
\hline $11^{b}$ & $\phi F R 114$ & - & - & - & + & - \\
\hline $4^{b}$ & $\phi F R-C$ & + & + & + & + & - \\
\hline $1^{c}$ & $\phi S a G 1$ & - & - & - & - & - \\
\hline
\end{tabular}

${ }^{a} n$ is the number of strains tested.

${ }^{b}$ None of these phages produced plaques on Pseudonocardia thermophila and strains of Saccharomonospora species.

c Species-specific phage for Saccharomonospora viridis.

scriptase was used and on chemotaxonomic studies. The genera of this family fall into the following three subclusters: (i) Pseudonocardia, Saccharopolyspora, and Faenia (the PSF group), (ii) Saccharomonospora and Amycolatopsis, and (iii) Actinopolyspora halophila. The last group can be clearly separated from the other two groups on the basis of polar lipids and a principal components analysis of its fatty acid composition. The genus Amycolata, which also has type IV cell walls and no mycolic acids, currently holds an isolated position and has not been clearly regarded as a genus of the Pseudonocardiaceae. This approach to the taxonomy of actinomycetes shows that the time-honored morphological criteria for the separation of genera have to be replaced by chemotaxonomic properties and that morphological fine structures should be used mainly at the species level.

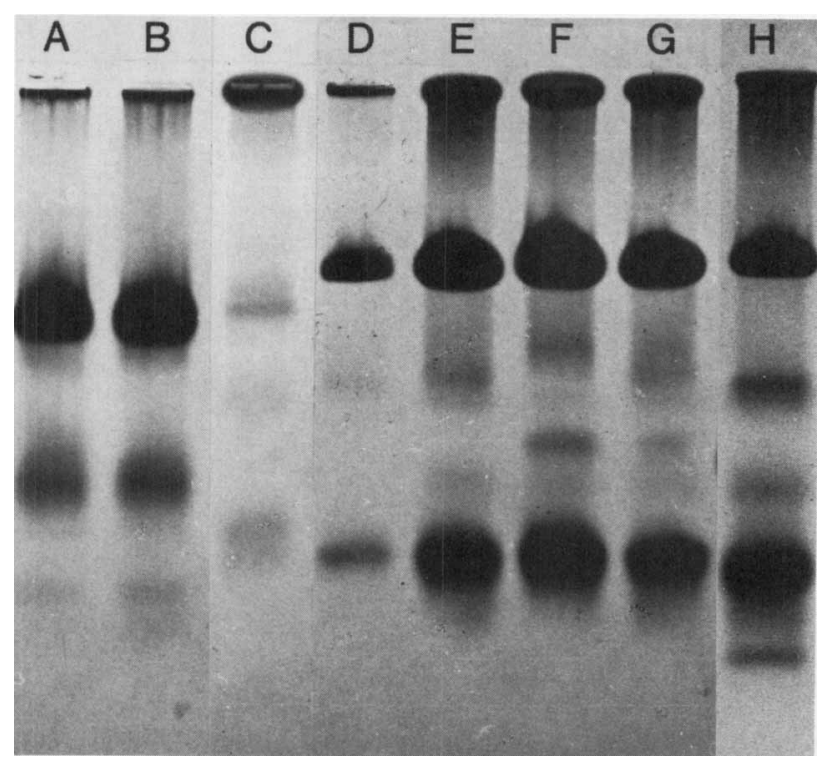

FIG. 3. Esterase patterns of strains of Saccharopolyspora species in a native $5 \%$ polyacrylamide slab gel. Lane A, Saccharopolyspora hirsuta DSM $43463^{\mathrm{T}}$; lane B, Saccharopolyspora hirsuta DSM 43401; lane C, Saccharopolyspora taberi DSM $43856^{\mathrm{T}}$; lane D, Saccharopolyspora erythraea NRRL $2338^{\mathrm{T}}$; lanes E through $\mathrm{H}$, Saccharopolyspora rectivirgula DSM 43371, DSM $43747^{\mathrm{T}}$, DSM 43755, and TF15, respectively.

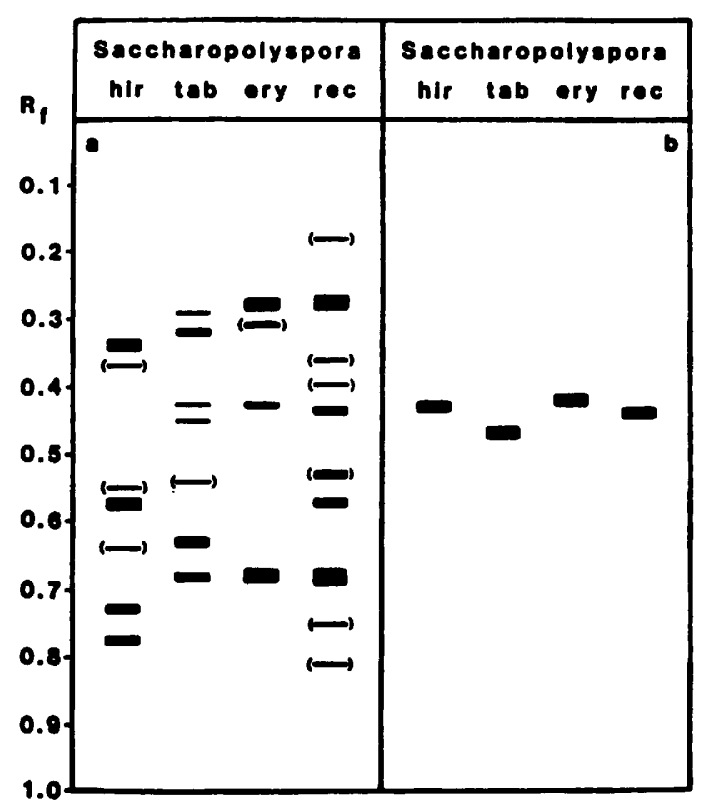

FIG. 4. Enzyme patterns of the four Saccharopolyspora species. (a) Esterase patterns. (b) Malate dehydrogenase patterns. The bands in parentheses are not common to all strains or are not always detectable, depending on the age of the culture. hir, Saccharopolyspora hirsuta; tab, Saccharopolyspora taberi; ery, Saccharopolyspora erythaea; rec, Saccharopolyspora rectivirgula.

Our detailed study of 24 strains that are representative of the genera Saccharopolyspora and Faenia confirmed the close relationship observed previously by several other authors $(6-9,31,32)$. The results of our extensive biochemical and molecular characterization (especially the fatty acid, phospholipid, and menaquinone patterns) clearly suggest that the species Faenia rectivirgula belongs in the genus Saccharopolyspora. Also, studies of phage sensitivity have been very useful taxonomic aids to supplement cell wall chemistry and have been described for several other genera belonging to the Actinomycetales $(23,27,37,45,46)$. The host ranges of our 23 phages, forming four groups, support the union of the two genera Faenia and Saccharopolyspora. However, Pseudonocardia thermophila, the third genus of subcluster 1 of Embley et al. (9), could be differentiated from the species of the genus Saccharopolyspora on the basis of menaquinone and fatty acid patterns, as well as phage typing. Similar results were obtained with the genera of subcluster 2 of Embley et al., which exhibited different menaquinone, fatty acid, and polar lipid patterns. As expected, the members of the genus Saccharomonospora (our data), as well as the members of the genus Amycolatopsis (Schneider, personal communication), were resistant to the Saccharopolyspora phages. Similar results were obtained by Labeda (30) with Saccharopolyspora erythraea phages PhiC69 and PhiSC17, which were quite specific and did not lyse any of the Amycolata or Amycolatopsis species tested by this author.

The close relationship between the genera Saccharopolyspora and Faenia was mentioned previously by Lacey (31), as follows: " $S$. hirsuta has never been systematically compared with Micropolyspora or with species of Nocardia, such as $N$. aerocolonigenes, $N$. autotrophica, $N$. mediterranea and $N$. orientalis, which lack mycolic acids. Saccharopolyspora could perhaps provide a home for some of these species or, if a close relationship were found, it could 


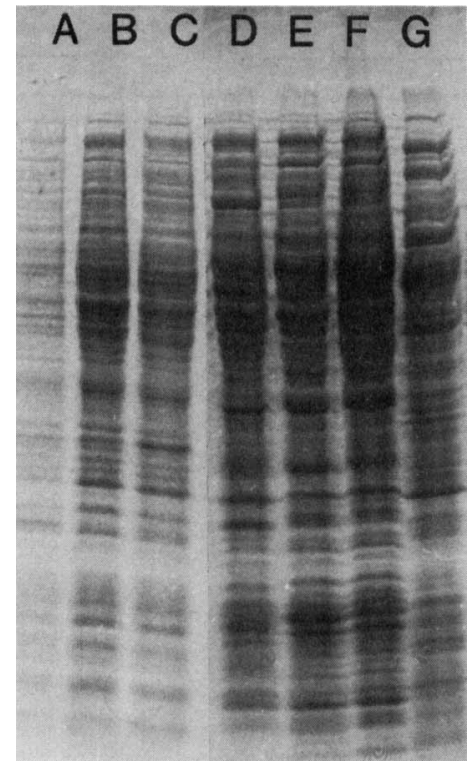

FIG. 5. Protein patterns of Saccharopolyspora species separated in a sodium dodecyl sulfate-polyacrylamide disc gel. Samples were electrophoresed from top to bottom. Lanes A through C, Saccharopolyspora hirsuta strains (lane B, strain DSM $43463^{\mathrm{T}}$ ); lane D, Saccharopolyspora taberi DSM $43856^{\mathrm{T}}$; lanes E and F, Saccharopolyspora erythraea strains (lane F, strain DSM $40517^{\mathrm{T}}$ ); lane G, Saccharopolyspora rectivirgula DSM $43747^{\mathrm{T}}$.

possibly be absorbed into Micropolyspora." Our results confirmed the relationship of Faenia (syn. Micropolyspora) to Saccharopolyspora, and we therefore propose transfer of Faenia rectivirgula to the genus Saccharopolyspora as Saccharopolyspora rectivirgula comb nov. and elimination of the genus Faenia in accordance with Rule $37 \mathrm{a}$ of the Inter- national Code of Nomenclature of Bacteria (34). The new species Saccharopolyspora rectivirgula can be separated from the other species of the genus (Saccharopolyspora hirsuta and Saccharopolyspora erythraea) by morphological properties and some physiological properties, as well as by DNA restriction, protein, and enzyme patterns. This is also true for Saccharopolyspora hirsuta subsp. taberi, which we regard as a separate species, Saccharopolyspora taberi. A description of the genus Saccharopolyspora has been given by Lacey in Bergey's Manual of Systematic Bacteriology (31), but it should be emended to include the information below,

Emended description of the genus Saccharopolyspora (Lacey and Goodfellow 1975). Saccharopolyspora (Sac' cha. ro. po. ly. spo. ra. M.L. Saccharum, generic name of sugar cane; Gr. adj. polys, many; Gr. n. spora, a seed; M.L. fem. n. Saccharopolyspora, the many-spored [organism] from sugar cane). Aerobic, gram positive, non-acid fast. Substrate mycelium yellow, orange, or brownish red on GYM agar and TSA, well developed, branched, septate, and 0.4 to $0.8 \mu \mathrm{m}$ in diameter. Substrate hyphae either (i) fragment into rodshaped elements, (ii) do not fragment, or (iii) are transformed partially into chains of spores. Aerial mycelium white to pinkish red or no aerial mycelium on GYM agar and TSA. When present, the aerial mycelium is 0.5 to $1.2 \mu \mathrm{m}$ in diameter and well developed in the presence of $5 \% \mathrm{NaCl}$. Spores occur in straight or open spiral chains on short, unbranched, lateral or terminal sporophores. Spore surfaces are smooth, rough, hairy, or spiny. Mesophilic, moderately thermophilic, or thermophilic, growing at temperatures up to $63^{\circ} \mathrm{C}$. Lysozyme sensitive. Melanoid pigment is not produced. No egg yolk reaction and no hemolysis. Able to utilize a wide range of organic compounds as sole sources of carbon for energy and growth and to degrade a number of substrates. Sensitive to genus-specific phages isolated from lysogenic cultures or from soil (e.g., $\phi F R-C)$.

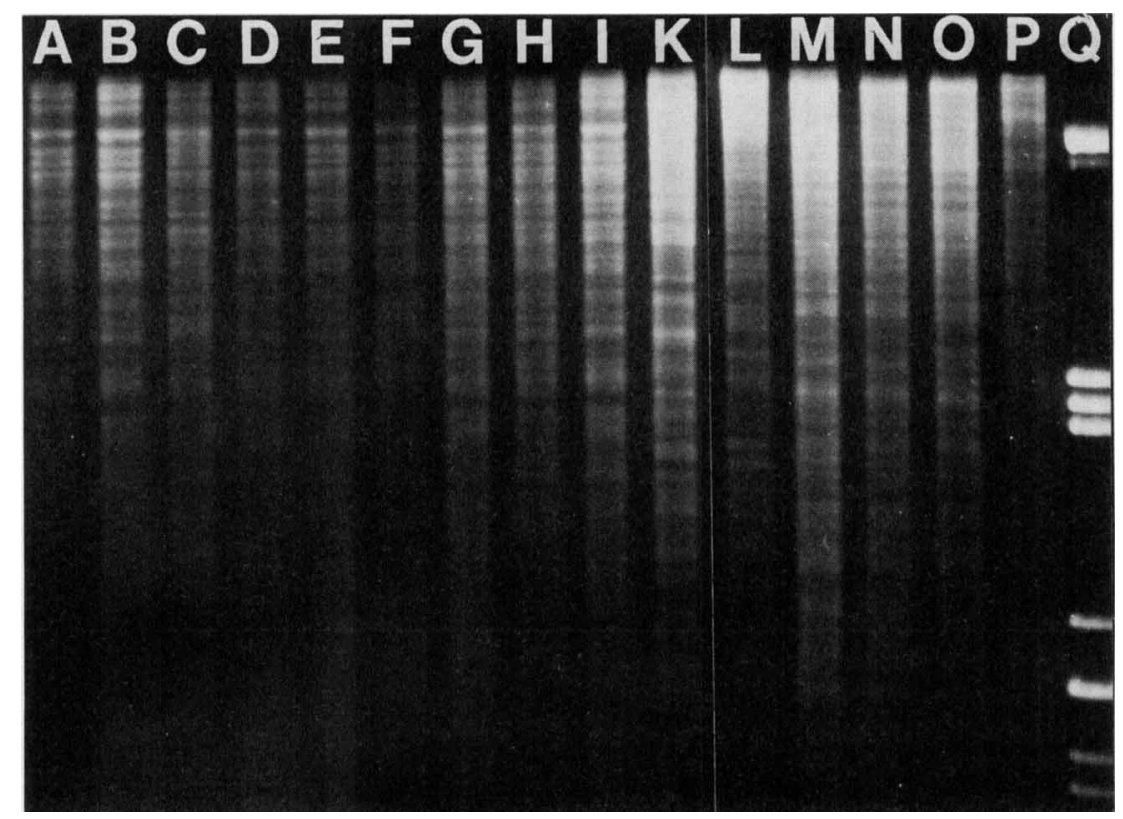

FIG. 6. Restriction patterns of chromosomal DNAs of Saccharopolyspora species and Pseudonocardia thermophila after digestion with endonuclease BglII. Lanes A through I, Saccharopolyspora rectivirgula strains (lane D, strain DSM $43747^{\mathrm{T}}$ ); lane K, Saccharopolyspora taberi DSM 43856 ${ }^{\mathrm{T}}$; lane L, Saccharopolyspora erythraea DSM $40517^{\mathrm{T}}$; lanes M through O, Saccharopolyspora hirsuta strains (lane M, strain DSM 43463 ${ }^{\mathrm{T}}$ ); lane P, Pseudonocardia thermophila DSM 43027; lane Q, $\lambda$ Pst I. 
Cell wall type IV with meso-DAP, arabinose, and galactose; no mycolic acids. Phosopholipid type III with mainly phosphatidylcholine and phosphatidylmethylethanolamine, as well as phosphatidylethanolamine. The predominant menaquinone is $\mathrm{MK}-9\left(\mathrm{H}_{4}\right)$. The $\mathrm{G}+\mathrm{C}$ content of the DNA is 70.4 to $71.5 \mathrm{~mol} \%$. The type species is Saccharopolyspora hirsuta (type strain, strain DSM 43463 [= NRRL B-5792]).

The descriptions of Saccharopolyspora rectivirgula and Saccharopolyspora taberi below are based on the data of Lacey (32) and Labeda (30), respectively, emended by our data.

Description of Saccharopolyspora rectivirgula (Kurup and Agre 1983) comb. nov. Saccharopolyspora rectivirgula (rec' ti. vir. gu. la. L. adj. rectus, straight; L. n. virgula, twig; M. L. n. rectivirgula, straight twig). Basonym, Faenia rectivirgula; synonym, Micropolyspora faeni. Aerobic, gram positive, non-acid fast. Substrate mycelium yellow to orange on GYM agar and TSA, well developed, branched, septate, and 0.5 to $0.8 \mu \mathrm{m}$ in diameter. Aerial mycelium white to light pink on GYM agar and TSA, 0.8 to $1.2 \mu \mathrm{m}$ in diameter, and well developed in the presence of $5 \% \mathrm{NaCl}$. Spores in chains on both substrate and aerial hyphae on short, unbranched, lateral or terminal sporophores. Spore formation basipetal. Spore surfaces rough. Strains of Saccharopolyspora rectivirgula are thermophilic and grow at temperatures ranging from 37 to $63^{\circ} \mathrm{C}$, with optimum growth at $50^{\circ} \mathrm{C}$. Growth in the presence of $10 \% \mathrm{NaCl}$. Lysozyme sensitive. Melanoid pigment is not produced. No egg yolk reaction and no hemolysis. Esculin, arbutin, urea, allantoin, and uric acid are hydrolyzed. Xanthine, hypoxanthine, tyrosine, gelatin, and casein are degraded; adenine, elastin, starch, chitin, and xylan are not degraded. Glucose, xylose, fructose, sucrose, raffinose, mannitol, and inositol are utilized as sole carbon sources; L-arabinose is not. Lactose and rhamnose are doubtful as sole carbon sources. All strains of Saccharopolyspora rectivirgula are lysed by the five lytic Saccharopolyspora rectivirgula phages (e.g., P113). The nonlysogenic strains are lysed by all temperate Saccharopolyspora rectivirgula phages (e.g., $\phi \mathrm{FR} 114$ and $\phi \mathrm{FR}-\mathrm{C}$ ) and three Saccharopolyspora erythraea phages (e.g., P517).

Cell wall type IV with meso-DAP, arabinose, and galactose; no mycolic acids. Phospholipid type III with mainly phosphatidylcholine and phosphatidylmethylethanolamine; smaller amounts of phosphatidylethanolamine are also found. The predominant menaquinones are $\mathrm{MK}-9\left(\mathrm{H}_{4}\right)$ and MK-10 $\left(\mathrm{H}_{4}\right)$; smaller amounts of MK-9( $\left.\mathrm{H}_{2}\right)$ and MK-9( $\left.\mathrm{H}_{6}\right)$ are also present. The $\mathrm{G}+\mathrm{C}$ content of the DNA is 70.4 mol\%. Isolated from moldy hay, soil, compost, and manure; causative agent of farmer's lung disease. The type strain is strain DSM 43747 (= ATCC 33515 = INMI 683).

Description of Saccharopolyspora taberi (Labeda 1987). sp. nov. Saccharopolyspora taberi (ta' ber.i. L. gen. n. taberi, named after Willard A. Taber, Texas A\&M University, who first isolated this organism). Substrate mycelium ranges from yellow to orange and from reddish to brownish red on GYM agar and TSA, respectively. No aerial mycelium and spores have been observed. Saccharopolyspora taberi is mesophilic, growing at temperatures ranging from 20 to $45^{\circ} \mathrm{C}$; optimum growth occurs at $37^{\circ} \mathrm{C}$. Poor growth in the presence of $7 \% \mathrm{NaCl}$. Lysozyme sensitive. Melanoid pigment is not produced. No hemolysis and egg yolk reaction. Esculin, arbutin, urea, allantoin, and uric acid are hydrolyzed. Adenine, xanthine, hypoxanthine, tyrosine, gelatin, casein, elastin, starch, and chitin are degraded. Xylan and DNA are not degraded. Glucose, xylose, fructose, rhamnose, lactose, sucrose, raffinose, mannitol, and inositol are utilized as sole carbon sources; L-arabinose is not. Produces the dark red metabolite texazone [2-( $N$-methylamino)-3H-phenoxazin-3one-8-carboxylic acid]. Saccharopolyspora taberi is lysed by three Saccharopolyspora erythraea phages (e.g., P517) and four temperate Saccharopolyspora rectivirgula phages (e.g., $\phi$ FR-C).

Cell wall type IV with meso-DAP, arabinose, and galactose; no mycolic acids. Phospholipid type III with mainly phosphatidylcholine, phosphatidylmethylethanolamine, and phosphatidylethanolamine. The menaquinones are MK$9\left(\mathrm{H}_{4}\right)$, MK-10 $\left(\mathrm{H}_{4}\right)$, and MK-9 $\left(\mathrm{H}_{2}\right)$. The $\mathrm{G}+\mathrm{C}$ content of the DNA is $70.8 \mathrm{~mol} \%$. Isolated from soil in Texas. The type strain is strain DSM 43856 (= NRRL B-16173 = LLWRAT-210).

\section{ACKNOWLEDGMENTS}

We thank Angelika Lieke and Andrea Herrmann for technical assistance, Adriano Majazza for taking the electron micrographs, Jörg Schneider for phage typing, Edith Greiner-Mai for supplying some isolates and determining malate dehydrogenase, and M. Embley (London, United Kingdom) for discussion of the paper.

This work was supported by grants GBF $87 / 06$ and 88/04 from the Bundesministerium für Forschung und Technologie, Federal Republic of Germany.

\section{LITERATURE CITED}

1. Arden Jones, M. P., A. J. McCarthy, and T. Cross. 1979. Taxonomic and serological studies on Micropolyspora faeni and Micropolyspora strains from soil bearing the specific epithet rectivirgula. J. Gen. Microbiol. 115:343-354.

2. Becker, B., M. P. Lechevalier, and H. A. Lechevalier. 1965. Chemical composition of cell-wall preparations from strains of various form-genera of aerobic actinomycetes. Appl. Microbiol. 13:236-243.

3. Brummund, W., V. P. Kurup, A. Resnick, T. J. Milson, and J. N. Fink. 1988. Immunologic response to Faenia-rectivirgula (Micropolyspora-faeni) in a dairy farm family. J. Allergy Clin. Immunol. 82:190-195.

4. Collins, M. D., R. M. Kroppenstedt, J. Tamaoka, K. Komagata, and T. Kinoshita. 1988. Structures of the tetrahydrogenated menaquinones from Actinomadura angiospora, Faenia rectivirgula and Saccharothrix australiensis. Curr. Microbiol. 17:275279.

5. Collins, M. D., T. Pirouz, M. Goodfellow, and D. E. Minnikin. 1977. Distribution of menaquinones in actinomycetes and corynebacteria. J. Gen. Microbiol. 100:221-230.

6. Embley, T. M., M. Goodfellow, A. G. O'Donnell, D. Rose, and D. E. Minnikin. 1986. Chemical criteria in the classification of some mycolateless wall chemotype IV actinomycetes, p. 553556. In G. Szabo, S. Biro, and M. Goodfellow (ed.), Biological, biochemical, and biomedical aspects of actinomycetes. Academiai Kiado, Budapest.

7. Embley, T. M., A. G. O'Donnell, J. Rostron, and M. Goodfellow. 1988. Chemotaxonomy of wall type IV actinomycetes which lack mycolic acids. J. Gen. Microbiol. 134:953-960.

8. Embley, T. M., J. Smida, and E. Stackebrandt. 1988. Reverse transcriptase sequencing of $16 \mathrm{~S}$ ribosomal RNA from Faenia rectivirgula, Pseudonocardia thermophila and Saccharopolyspora hirsuta, three wall type IV actinomycetes which lack mycolic acids. J. Gen. Microbiol. 134:961-966.

9. Embley, T. M., J. Smida, and E. Stackebrandt. 1988. The phylogeny of mycolate-less wall chemotype IV actinomycetes and description of Pseudonocardiaceae fam. nov. Syst. Appl. Microbiol. 11:44-52.

10. Embley, T. M., R. Wait, G. Dobson, and M. Goodfellow. 1987. Fatty acid composition in the classification of Saccharopolyspora hirsuta. FEMS Microbiol. Lett. 41:131-135.

11. Goodfellow, M., and T. Cross. 1984. Classification, p. 7-164. In M. Goodfellow, M. Modarski, and S. T. Williams (ed.), The 
biology of the actinomycetes. Academic Press, Inc. (London), Ltd., London.

12. Greiner-Mai, E., A. Kempf, F. Korn-Wendisch, and H. J. Kutzner. 1988. Studies on the causative agents of Farmer's lung: the actinomycete genera Faenia, Saccharomonospora and Thermoactinomyces, p. 491-496. In D. Behrens (ed.), Technology of biological processes-safety in biotechnology-applied genetic engineering. DECHEMA Biotechnology Conferences, vol. 1. VCH Verlagsgesellschaft, Weinheim, Federal Republic of Germany.

13. Greiner-Mai, E., F. Korn-Wendisch, and H. J. Kutzner. 1988. Taxonomic revision of the genus Saccharomonospora and description of Saccharomonospora glauca sp. nov. Int. J. Syst. Bacteriol. 38:398-405.

14. Greiner-Mai, E., R. M. Kroppenstedt, F. Korn-Wendisch, and H. J. Kutzner. 1987. Morphological and biochemical characterization and emended descriptions of thermophilic actinomycetes species. Syst. Appl. Microbiol. 9:97-106.

15. Henssen, A., H. W. Kothe, and R. M. Kroppenstedt. 1987. Transfer of Pseudonocardia azurea and "Pseudonocardia fastidiosa" to the genus Amycolatopsis, with emended species description. Int. J. Syst. Bacteriol. 37:292-295.

16. Hofheinz, W., and H. Grisebach. 1965. Die Fettsäuren von Streptomyces erythraeus und Streptomyces halstedii. Z. Naturforsch. 20b:43-53.

17. Hopwood, D. A., M. J. Bibb, K. F. Chater, T. Kieser, C. J. Bruton, H. M. Kieser, D. J. Lydiate, C. P. Smith, J. M. Ward, and H. Schrempf. 1985. Genetic manipulation of Streptomyces, a laboratory manual. The John Innes Foundation, Norwich, England.

18. Hsu, S. C., and J. L. Lockwood. 1975. Powdered chitin agar as a selective medium for enumeration of actinomycetes in water and soil. Appl. Microbiol. 29:422-426.

19. Kempf, A., E. Greiner-Mai, J. Schneider, F. Korn-Wendisch, and H. J. Kutzner. 1987. A group of actinophages of Faenia rectivirgula. Curr. Microbiol. 15:283-285.

20. Korn, F., B. Weingärtner, and H. J. Kutzner. 1978. A study of twenty actinophages: morphology, serological relationship and host range, p. 251-270. In E. Freerksen, I. Tarnok, and J. H. Thumin (ed.), Genetics of the Actinomycetales. Gustav Fischer Verlag, Stuttgart, Federal Republic of Germany.

21. Kroppenstedt, R. M. 1982. Separation of bacterial menaquinones by HPLC using reversed phase (RP18) and silver loaded ion exchanger as stationary phases. J. Liq. Chromatogr. 5: 2359-2367.

22. Kroppenstedt, R. M. 1985. Fatty acid and menaquinone analysis of actinomycetes and related organisms, p. 173-199. In M. Goodfellow and D. E. Minnikin (ed.), Chemical methods in bacterial systematics. Academic Press, Inc. (London), Ltd., London.

23. Kroppenstedt, R. M., F. Korn-Wendisch, V. J. Fowler, and E. Stackebrandt. 1981. Biochemical and molecular genetic evidence for a transfer of Actinoplanes armeniacus into the family Streptomycetaceae. Zentralbl. Bakteriol. Parasitenkd. Infektionskr. Hyg. Abt. 1 Orig. Reihe C 2:254-262.

24. Kroppenstedt, R. M., and H. J. Kutzner. 1978. Biochemical taxonomy of some problem actinomycetes. Zentralbl. Bakteriol. Mikrobiol. Hyg. Abt. 1 Suppl. 6:125-133.

25. Kurup, V. P. 1984. Thermophilic actinomycetes: their role in hypersensitivity pneumonitis, p. 145-159. In L. Ortiz-Ortiz, L. F. Bojalil, and V. Yakoleff (ed.), Biological, biochemical, and biomedical aspects of actinomycetes. Academic Press, Inc. (London), Ltd., London.

26. Kurup, V. P., and N. S. Agre. 1983. Transfer of Micropolyspora rectivirgula (Krassil'nikov and Agre) Lechevalier, Lechevalier and Becker, 1966 to Faenia gen. nov. Int. J. Syst. Bacteriol. 33:663-665.

27. Kurup, V. P., and J. N. Fink. 1975. A scheme for the identification of thermophilic actinomycetes associated with hypersensitivity pneumonitis. J. Clin. Microbiol. 2:55-61.

28. Kurup, V. P., and J. N. Fink. 1979. Antigens of Micropolyspora faeni strains. Int. Arch. Allergy Appl. Immunol. 60:140-147.

29. Kutzner, H. J. 1981. The family Streptomycetaceae, p. 2028-
2090. In M. P. Starr, H. Stolp, H. G. Trüper, A. Balows, and H. G. Schlegel (ed.), The prokaryotes. Springer-Verlag, Berlin. 30. Labeda, D. P. 1987. Transfer of the type strain of Streptomyces erythraeus (Waksman 1923) Waksman and Henrici 1948 to the genus Saccharopolyspora Lacey and Goodfellow 1975 as Saccharopolyspora erythraea sp. nov. and designation of a neotype strain for Streptomyces erythraeus. Int. J. Syst. Bacteriol. 37:19-22.

31. Lacey, J. 1986. Genus Saccharopolyspora Lacey and Goodfellow 1975, p. 1492-1496. In P. H. A. Sneath, N. S. Mair, M. E. Sharpe, and J. G. Holt (ed.), Bergey's manual of systematic bacteriology, vol. 2. The Williams \& Wilkins Co., Baltimore.

32. Lacey, J. 1986. Genus Micropolyspora Lechevalier, Solotorovsky and McDurmont 1961, p. 1496-1501. In P. H. A. Sneath, N. S. Mair, M. E. Sharpe, and J. G. Holt (ed.), Bergey's manual of systematic bacteriology, vol. 2. The Williams \& Wilkins Co., Baltimore.

33. Lacey, J., and M. Goodfellow. 1975. A novel actinomycete from sugar-cane bagasse: Saccharopolyspora hirsuta gen. et sp. nov. J. Gen. Microbiol. 88:75-85.

34. Lapage, S. P., P. H. A. Sneath, E. F. Lessel, V. B. D. Skerman, H. P. R. Seeliger, and W. A. Clark (ed.). 1975. International code of nomenclature of bacteria. 1975 Revision. American Society for Microbiology, Washington, D.C.

35. Lechevalier, M. P., C. de Bievre, and H. A. Lechevalier. 1977. Chemotaxonomy of aerobic actinomycetes: phospholipid composition. Biochem. Syst. Ecol. 5:249-260.

36. Lechevalier, M. P., and H. A. Lechevalier. 1970. Chemical composition as a criterion in the classification of aerobic actinomycetes. Int. J. Syst. Bacteriol. 20:435-444.

37. Lechevalier, M. P., H. Prauser, D. P. Labeda, and J.-S. Ruan. 1986. Two new genera of nocardioform actinomycetes: Amycolata gen. nov. and Amycolatopsis gen. nov. Int. J. Syst. Bacteriol. 36:29-37.

38. Minnikin, D. E., L. Alshamaony, and M. Goodfellow. 1975 Differentiation of Mycobacterium, Nocardia, and related taxa by thin layer chromatographic analysis of whole-cell methanolysates. J. Gen. Microbiol. 88:200-204.

39. Minnikin, D. E., A. G. O'Donnell, M. Goodfellow, G. Alderson, M. Athalye, A. Schaal, and J. H. Parlett. 1984. An integrated procedure for extraction of bacterial isoprenoid quinones and polar lipids. J. Microbiol. Methods 2:233-241.

40. Moore, W. E. C., E. P. Cato, and L. V. H. Moore. 1985. Index of bacterial and yeast nomenclatural changes published in the International Journal of Systematic Bacteriology since the 1980 Approved Lists of Bacterial Names (1 January 1980-1 January 1985). Int. J. Syst. Bacteriol. 35:382-407.

41. Okazaki, T., R. Enokita, H. Miyaoka, T. Takatsu, and A. Torikata. 1987. Chloropolysporins A, B and C, novel glycopeptide antibiotics from Faenia interjecta sp. nov. I. Taxonomy of the producing organism. J. Antibiot. 60:917-923.

42. Owen, R. J., and D. Pitcher. 1985. Current methods for estimating DNA base composition and levels of DNA-DNA hybridization. Soc. Appl. Bacteriol. Tech. Ser. 20:67-93.

43. Pepys, J., P. A. Jenkins, G. N. Festenstein, P. H. Gregory, M. E. Lacey, and F. A. Skinner. 1963. Farmer's lung: thermophilic actinomycetes as a source of "farmer's lung hay" antigen. Lancet ii:607-611.

44. Poschner, J., R. M. Kroppenstedt, A. Fischer, and E. Stackebrandt. 1985. DNA-DNA reassociation and chemotaxonomic studies on Actinomadura, Microbispora, Microtetraspora, Micropolyspora and Nocardiopsis. Syst. Appl. Microbiol. 6:264 270.

45. Prauser, H. 1984. Phage host ranges in the classification and identification of gram-positive branched and related bacteria, $p$. 617-634. In L. Ortiz-Ortiz, L. F. Bojalil, and V. Yakoleff (ed.), Biological, biochemical, and biomedical aspects of actinomycetes. Academic Press, Inc. (London), Ltd., London.

46. Prauser, H., and S. Momirova. 1970. Phagensensibilität, Zellwandzusammensetzung und Taxonomie einiger thermophiler Actinomyceten. Z. Allg. Mikrobiol. 10:367-369.

47. Schneider, J., and H. J. Kutzner. 1989. Distribution of modules 
among the central regions of the genomes of several actinophages of Faenia and Saccharopolyspora. J. Gen. Microbiol. 135:1671-1678.

48. Shirling, E. B., and D. Gottlieb. 1966. Methods for characterization of Streptomyces species. Int. J. Syst. Bacteriol. 16: 313-340.

49. Skerman, V. B. D., V. McGowan, and P. H. A. Sneath (ed.). 1980. Approved lists of bacterial names. Int. J. Syst. Bacteriol. 30:225-420.
50. Stanek, J. L., and G. D. Roberts. 1974. Simplified approach to identification of aerobic actinomycetes by thin-layer chromatography. Appl. Microbiol. 28:226-231.

51. Uchida, K., and K. Aida. 1977. Acyl type of bacterial cell wall: its simple identification by colorometric methods. J. Gen. Appl. Microbiol. 23:249-260.

52. Tamaoka, J., and K. Komagata. 1984. Determination of DNA base composition by reversed-phase high-performance liquid chromatography. FEMS Microbiol. Lett. 25:125-128. 